\title{
Fate of increased production in late-summer plankton communities due to nutrient enrichment of the Baltic Proper
}

\author{
P. Kuuppo ${ }^{1, *}$, K. Samuelsson ${ }^{2,3}$, R. Lignell ${ }^{1,4}$, J. Seppäläa,4, T. Tamminen , \\ A. Andersson ${ }^{2,3}$ \\ ${ }^{1}$ Finnish Environment Institute, PO Box 140, 00251 Helsinki, Finland \\ ${ }^{2}$ Marine Ecology, Dept of Ecology and Environmental Science, Umeå University, 90187 Umeå, Sweden \\ ${ }^{3}$ Umeå Marine Sciences Centre, Norrbyn, 91020 Hörnefors, Sweden \\ ${ }^{4}$ Present address: Finnish Institute of Marine Research, PO Box 33, 00931 Helsinki, Finland
}

\begin{abstract}
The fate of increased production due to nutrient enrichment was studied experimentally in late-summer plankton communities in the central Baltic Sea in 1997 and 1998. In the first year, inorganic nitrogen and phosphorus, as well as labile organic carbon, were added to natural and $0.8 \mu \mathrm{m}$ pre-filtered seawater in a $2^{3}$ factorial design, and the response of the heterotrophic bacterial community was followed. In the second year, 2 experiments were carried out, where the response of the whole microbial community to nutrient and carbon enrichments was studied. In the first of those experiments, the seawater was pre-filtered through a $40 \mu \mathrm{m}$ filter to exclude filamentous cyanobacteria. In the second experiment, a 40 -fold concentrate of $>90 \mu \mathrm{m}$ plankton was added, resulting in a 9 -fold concentration of phytoplankton biomass compared to natural levels. All experiments were run for $3 \mathrm{~d}$ in a deck incubator equipped with continuous seawater flow. Phytoplankton primary production (PP) was limited by both nitrogen and phosphorus, while bacterial production (BP) was colimited by inorganic nutrients and labile carbon source. The increased PP resulted in a higher biomass of picocyanobacteria and phototrophic flagellates, while filamentous cyanobacteria showed no positive response. The increased BP did not result in a higher bacterial biomass (BB), indicating grazing control by protozoa. In accordance, higher flagellate and/or ciliate biomasses were observed in the enriched treatments. Picocyanobacteria therefore seemed to be less edible to protozoa than the heterotrophic bacteria. The increase in BP by carbon addition increased biomasses at the higher trophic levels more than the increase in PP, indicating a tighter link in the heterotrophic part of the microbial food web and an important pathway for organic material in regenerated conditions.
\end{abstract}

KEY WORDS: Nutrient limitation · Microbial food web · Baltic Sea $\cdot$ Cyanobacteria $\cdot$ Picoplankton Resale or republication not permitted without written consent of the publisher

\section{INTRODUCTION}

Since eutrophication has become an increasing problem in marine coastal and estuarine areas, the question of nutrient limitation of phytoplankton production and biomass has been central. It has been studied by a variety of methods such as nutrient contents of cells, nutrient uptake rates and physiological indicators (e.g. Granéli 1984, 1987, Sakshaug \& Olsen
1986, Zevenboom 1986, Hecky \& Kilham 1988 and references therein, Graziano et al. 1996, Hameed et al. 1999, Holmboe et al. 1999, Mallin et al. 1999, Seppälä et al. 1999). Bioassays, in which the response of phytoplankton primary production (PP) and biomass accumulation is followed after nutrient enrichment, have been used in several studies (Granéli et al. 1990, Kivi et al. 1993, Downing et al. 1999 and references therein). The overall conclusion of the bioassays carried out in 
coastal areas of the Baltic Sea is that the limiting nutrient varies not only areally but also seasonally between phosphorus and nitrogen, while the open sea areas are largely nitrogen limited (Granéli et al. 1988, Kivi et al. 1993, HELCOM 1996, Seppälä et al. 1999). Besides N and $\mathrm{P}, \mathrm{Fe}$ has also been suggested as limiting the growth of filamentous cyanobacteria in the open areas of the Baltic Sea (Stal et al. 1999).

The Baltic Sea is one of the many estuaries in the world that suffers from severe eutrophication problems (HELCOM 1996). In the open areas of the Baltic Sea, filamentous cyanobacteria regularly form late summer blooms, which are reported to have intensified and increased in frequency and duration (Kahru et al. 1994, Bianchi et al. 2000). These blooms are dominated by Aphanizomenon flos-aquae Ralfs, and Nodularia spumigena Mertens, which are both able to fix atmospheric nitrogen. N. spumigena blooms are frequently toxic (Sivonen et al. 1989).

Filamentous cyanobacterial blooms occur at the time when planktonic production relies largely on nitrogen and phosphorus regenerated within the planktonic food web. There is indication that the blooms are initiated in fronts, i.e. areas where different water masses meet, and where water with a low mineral $\mathrm{N}: \mathrm{P}$ ratio is introduced to the trophogenic layer from below the thermocline (Kononen et al. 1996 and references therein), thus giving the $\mathrm{N}$-fixing cyanobacteria a competitive advantage in a N-limited late-summer situation.

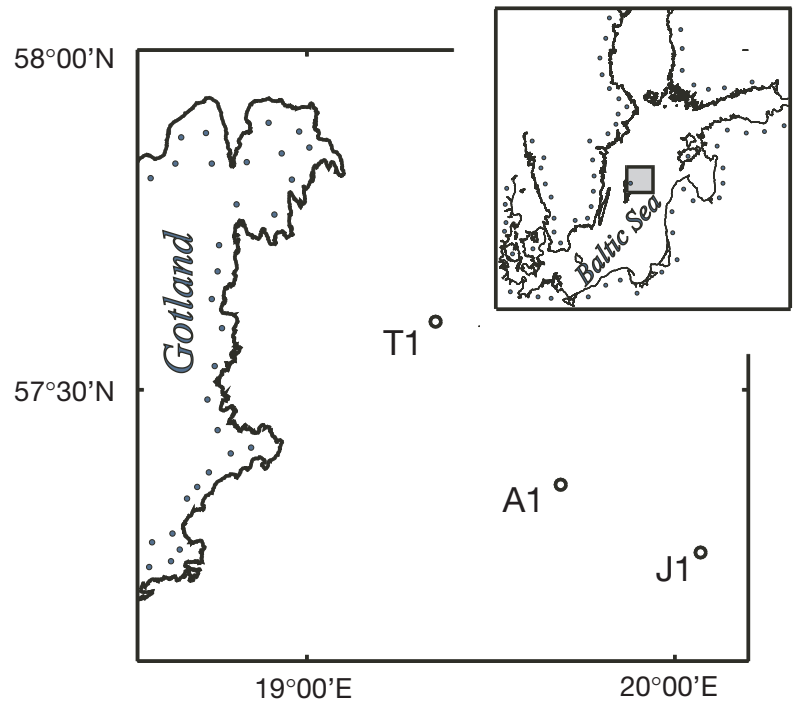

Fig. 1. Study area. For the first experiment, which focused on the heterotrophic bacterial community, water was sampled from Stn A1 on August 3 1997. The second experiment, with $<40 \mu \mathrm{m}$ prefractionation, was carried out with water sampled from Stn J1 (BY15) on July 31; the third experiment, with $>90 \mu \mathrm{m}$ concentrate, was carried out with water sampled from Stn T1, on August 61998
The role of the microbial food web in Baltic cyanobacterial blooms has been studied little (Heinänen et al. 1995). It is well known that microbes, especially protozoa, play an important role in the regeneration of nutrients in oligotrophic conditions (e.g. Johannes 1965, Caron \& Goldman 1990 and references therein). On the other hand, picoplankton, such as Synechococcus-type cyanobacteria and heterotrophic bacteria, are effective competitors of larger phytoplankton for nutrients, and can grow at maximal rates under oligotrophic conditions (Raven 1987, 1998). In many studies, planktonic bacteria have been found to be limited not only by inorganic nutrients, but also by a source of labile carbon (e.g. Kivi et al. 1993, Kuparinen \& Heinänen 1993, Zweifel et al. 1993, Rivkin \& Anderson 1997, Thingstad et al. 1998, Carlsson \& Caron 2001). Most nutrient enrichment bioassays with bacteria have been carried out in cultures free of predators and phytoplankton, where competition over inorganic nutrients between phyto- and bacterioplankton cannot be estimated. Moreover, the nutrient regeneration and release of labile DOC by protists (e.g. Johannes 1965, Taylor et al. 1985) cannot be taken into consideration in a system consisting only of bacteria.

In this study, we approached the question of nutrient and labile carbon limitation in the late-summer planktonic community in the oligotrophic central Baltic by nutrient enrichment bioassays. In the experiments, $\mathrm{N}$ and/or P limitation of phytoplankton, as well as N, P and $\mathrm{C}$ limitation of bacteria, was studied. The focus was on the potential nutrient competition between phytoplankton and bacteria, and food-web effects subsequent to the increased production of phyto- and bacterioplankton.

\section{MATERIALS AND METHODS}

Experimental setup. Cruises for project BASYS (EU/MAST III) to the Gotland Basin, central Baltic Sea, were carried out in late summer 1997 and 1998 (July 29 to August 10), on RV 'Baltica'. In 1997, heavy latephase blooms of filamentous cyanobacteria, with dense surface flocs as a consequence of sunny, calm and warm weather conditions, were studied. Before and during the 1998 cruise, the weather was stormy, with heavy southwesterly winds, and the blooms of filamentous cyanobacteria were still under development.

In the first experiment (August 3 1997), the effects of resource and grazing on bacterial production (BP) and biomass were studied. Water for the experiment was taken at Stn A1 $\left(57^{\circ} 21^{\prime} \mathrm{N}, 19^{\circ} 41^{\prime} \mathrm{E}\right.$, depth $100 \mathrm{~m}$; Fig. 1) from $4 \mathrm{~m}$ depth. Additions of carbon (36 $\mu \mathrm{M}$ glucose-C), nitrogen (6 $\left.\mathrm{MM} \mathrm{NH}_{4}-\mathrm{N}\right)$ and phosphorus $\left(0.6 \mu \mathrm{M} \mathrm{PO}_{4}\right.$-P) were made according to a $2^{3}$ factorial 
design (control treatment with no additions, and additions of $\mathrm{N}$ only, $\mathrm{P}$ only, combined $\mathrm{N}+\mathrm{P}, \mathrm{C}$ only, combined $\mathrm{C}+\mathrm{N}$, combined $\mathrm{C}+\mathrm{P}$ and combined $\mathrm{C}+\mathrm{N}+\mathrm{P})$ to $1 \mathrm{l}$ unfiltered or $0.510 .8 \mu \mathrm{m}$ filtered seawater in acidrinsed and seawater-rinsed polycarbonate bottles. All treatments were performed in duplicate. The bottles were placed in a deck incubator with a continuous flow-through of seawater to keep the temperature at the ambient level. The unfiltered treatments were incubated under a neutral density filter that removed $90 \%$ of the sunlight. To inhibit autotrophic plankton growth, the filtered treatments were incubated in darkness. Bacterial biomass (BB) and BP were followed for $72 \mathrm{~h}$ with a $24 \mathrm{~h}$ sampling interval.

In Expts 2 and 3 (July 31 and August 6 1998, respectively), effects of nutrient additions on the whole microbial food web were studied. Water for the experiments was taken from $5 \mathrm{~m}$ depth. For Expt $2(<40 \mu \mathrm{m}$ experiment) the water sample was taken from Stn J1 (57 $16^{\prime} \mathrm{N}, 20^{\circ} 04^{\prime} \mathrm{E}$, depth $240 \mathrm{~m}$; Fig.1) and prefiltered through $40 \mu \mathrm{m}$ plankton sieve to remove mesozooplankton and large aggregates. For Expt $3(>90 \mu \mathrm{m}$ experiment) the water sample from Stn T1 $\left(57^{\circ} 36^{\prime} \mathrm{N}\right.$, $19^{\circ} 22^{\prime}$ E, depth $110 \mathrm{~m}_{i}$ Fig. 1) was treated similarly, but an inoculum of ca. 40-fold $>90 \mu \mathrm{m}$ concentrate, obtained by net hauls from $8 \mathrm{~m}$ depth to the surface, was added to the experimental water. Concentrated inoculum from the net was first thoroughly mixed in the $<40 \mu \mathrm{m}$ filtrate and then distributed into acid-washed 81 polycarbonate flasks. In both 1998 experiments, nitrogen $\left(5.7 \mu \mathrm{M} \mathrm{NH}_{4}-\mathrm{N}\right)$, phosphorus $\left(0.6 \mu \mathrm{M} \mathrm{PO}_{4}-\mathrm{P}\right)$ and carbon (68 $\mu \mathrm{M}$ sucrose-C) were added on Day 0 according to a $2^{3}$ experimental design without replication. The phosphate addition was adjusted to reach the below-thermocline concentration. Ammonium was added in a $\mathrm{N}: \mathrm{P}$ ratio of 9.5 , and $\mathrm{C}: \mathrm{P}$ ratios were adjusted to the Redfield ratio. The experiment was run for $3 \mathrm{~d}$ in a deck incubator, with a continuous flowthrough of seawater ensuring that the in situ temperature was maintained. Excess light was screened with a neutral filter (Rosco) attached to a polythene sheet, allowing ca. $12 \%$ of the irradiance to pass to the experimental flasks. The experiments were started at ca. 09:00 h, and sampling was carried out at 0, 24, 48 and $72 \mathrm{~h}$ after the start.

Measurements. Inorganic nutrients were measured onboard with a Hitachi U-1100 spectrophotometer using standard procedures (Koroleff \& Grasshoff 1983). Chl a was measured onboard with a Shimadzu RFPC5001 spectrofluorometer, calibrated with pure chl a (Sigma), after filtration of 50 to $100 \mathrm{ml}$ aliquots onto Whatman GF/F filters and extraction in $96 \%$ ethanol for $24 \mathrm{~h}$ at room temperature.

In the $<40 \mu \mathrm{m}$ experiment, PP was measured in total, $<10 \mu \mathrm{m}$ and $<2 \mu \mathrm{m}$ prefractionated subsamples using the ${ }^{14} \mathrm{C}$ method (Steemann-Nielsen 1952, Lignell 1992). After addition of $\mathrm{NaH}^{14} \mathrm{CO}_{3}(1 \mu \mathrm{Ci}$ per $20 \mathrm{ml})$, the samples were incubated for $4 \mathrm{~h}$ in a water bath adjusted to in situ temperature and under artificial light (160 to $200 \mu \mathrm{mol}$ quanta $\mathrm{m}^{-2} \mathrm{~s}^{-1}$ ), which corresponded to, on average, $12 \%$ of the surface irradiance measured during the experiments. After incubation, acidified $(\mathrm{pH}<2) 4 \mathrm{ml}$ subsamples were left uncapped for $24 \mathrm{~h}$ (no bubbling), after which their radioactivity was measured with the LKB Wallac Rackbeta 1215 Liquid Scintillation Counter. The daily PP values were calculated using the irradiation measured onboard (LiCor LI-193SA, Spherical Quantum Sensor connected to a LI-1400 Datalogger).

BP was measured using the tritiated thymidine incorporation method (TTI) (Fuhrman \& Azam 1982, Smith \& Azam 1992). In 1997, $2 \times 1 \mathrm{ml}$ samples from each experimental unit were incubated with $10 \mathrm{nM}$ of tritiated thymidine (final concentration). The incubation was stopped after $60 \mathrm{~min}$ by adding ice-cold $50 \%$ trichloroacetic acid (TCA). Non-incorporated thymidine was washed away with ice-cold 5\% TCA, and centrifugation. In 1998, 3 replicates were used, the thymidine addition was $20 \mathrm{nM}$, and the $30 \mathrm{~min}$ incubation was stopped by adding $10 \mu \mathrm{l}$ of $37 \%$ formalin solution to the samples, which were then extracted with $10 \%$ TCA in ice-cold conditions, and washed 3 times with ice-cold 5\% TCA using centrifugation. The controls were treated in the same way as the samples after the bacteria had been prekilled by the addition of $50 \%$ TCA (1997) or $37 \%$ formalin (1998). Incorporated thymidine was counted with a Beckman LS 18101 or an LKB Wallac Rackbeta 1215 liquid scintillation counter. A conversion factor of $1 \times 10^{18}$ cells per mole of incorporated thymidine was used to calculate cell production (Heinänen \& Kuparinen 1992).

For bacterial enumeration, 1 to $3 \mathrm{ml}$ of formaldehyde-fixed subsample was filtered onto a $0.2 \mu \mathrm{m}$ black polycarbonate filter (Poretics) and stained with acridine orange (Hobbie et al. 1977). Nanoflagellates and picoalgae were fixed with unbuffered glutaraldehyde (final concentration 1\%), stained with proflavine (Haas 1982, Kuosa 1988) and filtered onto black Poretics filters (pore size $0.2 \mu \mathrm{m}$ ).

The cells were counted using an epifluorescence microscope, with a $100 \times$ oil immersion objective under blue (bacteria, nanoflagellates, and picoplanktonic eukaryotes) or green (picocyanobacteria) excitation. A total of 100 picocyanobacterial and bacterial cells were measured by eye using an ocular graticule at the beginning and end of the experiment. Their biovolume was calculated using a formula of a globe (cocci) or a cylinder (elongated cells). In 1997, an image analyser was used (Blackburn et al. 1998) for quantification of bacteria. Heterotrophic nanoflagellates were classified into 6 size 
categories, based on their cell length, using an ocular micrometer. In each size category, the biovolume was estimated using the formula of an ellipsoid with a flattened, round bottom. Autotrophic nanoflagellates were distinguished by their cell shape and red chlorophyll or orange phycoerythrin (cryptomonads) fluorescence. Their biovolume was calculated from cell dimensions using species-specific formulas (Tikkanen 1986). Ciliates and net-phytoplankton were counted with a Leitz Diavert inverted microscope from Lugol-preserved samples using the Utermöhl method (Utermöhl 1958).

Calculations. The biovolumes were converted to carbon using the following coefficients: $0.35 \mathrm{pgC}^{-3} \mathrm{~m}^{-3}$

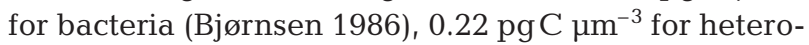
trophic nanoflagellates (Børsheim \& Bratbak 1987) and

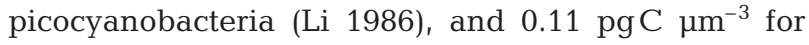
autotrophic nanoflagellates and picoeukaryotes (Edler 1979). Ciliates and net-phytoplankton were converted to biomass using their measured volumes and $0.11 \%$ carbon content (Edler 1979) in the calculations.

To evaluate the fate and effects of the increased bacterial and pico- and nanoalgal production on the microbial food web, a carbon budget was constructed from the $<40 \mu \mathrm{m}$ experiment. For the calculations, the control, NP and the CNP units were chosen, because major PP and BP responses to the inorganic nutrient and labile carbon additions were observed in those treatments. PP and BP values from the ${ }^{14} \mathrm{C}$ and TTI measurements were integrated over the $3 \mathrm{~d}$ period using the measured irradiance curve in the PP calculations. Biomass change was calculated as the difference between the initial and final biomasses in the experiment, and loss was calculated as the difference between the production-based biomass estimate and the microscopically observed biomass.

In the 1997 experiment the response in heterotrophic bacterial abundance and production to nutrient addition or predator removal was tested using ANOVA (SYSTAT). To fulfil the assumptions of homogeneity of variance, the data on BP was ln-transformed. To identify which treatments differed from the control, a 1-way ANOVA and Tukey's test was used.

\section{RESULTS}

\section{Effect of nutrient enrichment on the heterotrophic bacterial community}

The first experiment (1997) was started in a situation with high surface temperature and low inorganic nutrient concentrations (Table 1). The phytoplankton community was dominated by cyanobacteria and nanoflagellates, and a filamentous cyanobacterial bloom was floating in the upper $5 \mathrm{~m}$ of the water column. The fila- mentous cyanobacteria formed aggregates with associated pennate diatoms, bacteria and protists. Heterotrophic bacteria, flagellates and ciliates showed maximum abundances in the top $10 \mathrm{~m}\left(3-5 \times 10^{6}, 1-6 \times 10^{3}\right.$

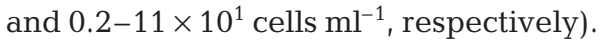

In the unfiltered treatments, the number of bacteria decreased with time (Fig. 2), indicating that grazing exceeded production. Concomitantly, BP increased in all treatments. The highest response, 3 -fold increase in the BP over the control, was observed in the treatment with both nutrients and carbon added (Fig. 2). These results indicate that the BB was limited by predation, while the $\mathrm{BP}$ was substrate limited. In the $0.8 \mu \mathrm{m}$-prescreened treatments, both biomass and production of bacteria increased $48 \mathrm{~h}$. The positive response of the bacterial number to removal of predators larger than $0.8 \mu \mathrm{m}$ confirms the result from the first part of the experiment. A significant positive effect of nutrient treatment (CNP) on the BP (ANOVA, $\mathrm{p}<0.05$ ), and a significant positive response of $\mathrm{BB}$ to predator exclusion (ANOVA, $\mathrm{p}<$ 0.05 ), were found after $48 \mathrm{~h}$ of incubation. Of the single nutrient additions, carbon gave the strongest response in BP (1-way ANOVA, p < 0.05 and Tukey's test). Additions of CP and CNP also gave significantly increased production rates (Tukey's test, $\mathrm{p}<0.05$ ). In conclusion, this experiment showed that increased BP due to nutrient enrichment was directly channelled to higher trophic levels. This led us to continue with studies on the entire microbial community.

\section{Effect of nutrient enrichment on the whole microbial community}

Initially, the $<40 \mu \mathrm{m}$ experiment represented a typical late summer situation in the Baltic Sea.

Table 1. Initial conditions at the beginning of the experiments in 1997 and 1998. Salinity and water temperature values are from the conductivity-temperature-depth (CTD) cast measurements from the sampling depths $(4$ or $5 \mathrm{~m}$ ). The other values are from the sample water after the pretreatments. N/P: $\mathrm{NH}_{4}+\mathrm{NO}_{3} / \mathrm{PO}_{4}$ i PP: primary production; BP: bacterial production

\begin{tabular}{|lcccc|}
\hline & \multicolumn{2}{c}{1997} & \multicolumn{2}{c|}{1998} \\
& $<0.8 \mu \mathrm{m}$ & Unfiltered & $<40 \mu \mathrm{m}$ & $>90 \mu \mathrm{m}$ \\
\hline Salinity $(\mathrm{psu})$ & & & 6.9 & 6.3 \\
Temperature $\left({ }^{\circ} \mathrm{C}\right)$ & 20 & 20 & 15.0 & 15.1 \\
$\mathrm{NH}_{4}-\mathrm{N}(\mu \mathrm{M})$ & 0.2 & 0.5 & 0.35 & 0.25 \\
$\mathrm{NO}_{3}-\mathrm{N}(\mu \mathrm{M})$ & $<0.05$ & $<0.05$ & 0.09 & 0.09 \\
$\mathrm{PO}_{4}-\mathrm{P}(\mu \mathrm{M})$ & $<0.01$ & $<0.01$ & 0.02 & 0.05 \\
$\mathrm{~N} / \mathrm{P}$ & $>25$ & 55 & 24.5 & 6.8 \\
$\mathrm{Chl} \mathrm{a}\left(\mu \mathrm{g} \mathrm{l}^{-1}\right)$ & & 1.6 & 2.3 & 8.3 \\
$\mathrm{PP}\left(\mu \mathrm{Cl} \mathrm{l}^{-1} \mathrm{~h}^{-1}\right)$ & & & 5.1 & 17.5 \\
$\mathrm{BP}\left(\mu \mathrm{C} \mathrm{l}^{-1} \mathrm{~h}^{-1}\right)$ & 0.5 & 0.6 & 1.0 & 0.5 \\
& & & & \\
\hline
\end{tabular}




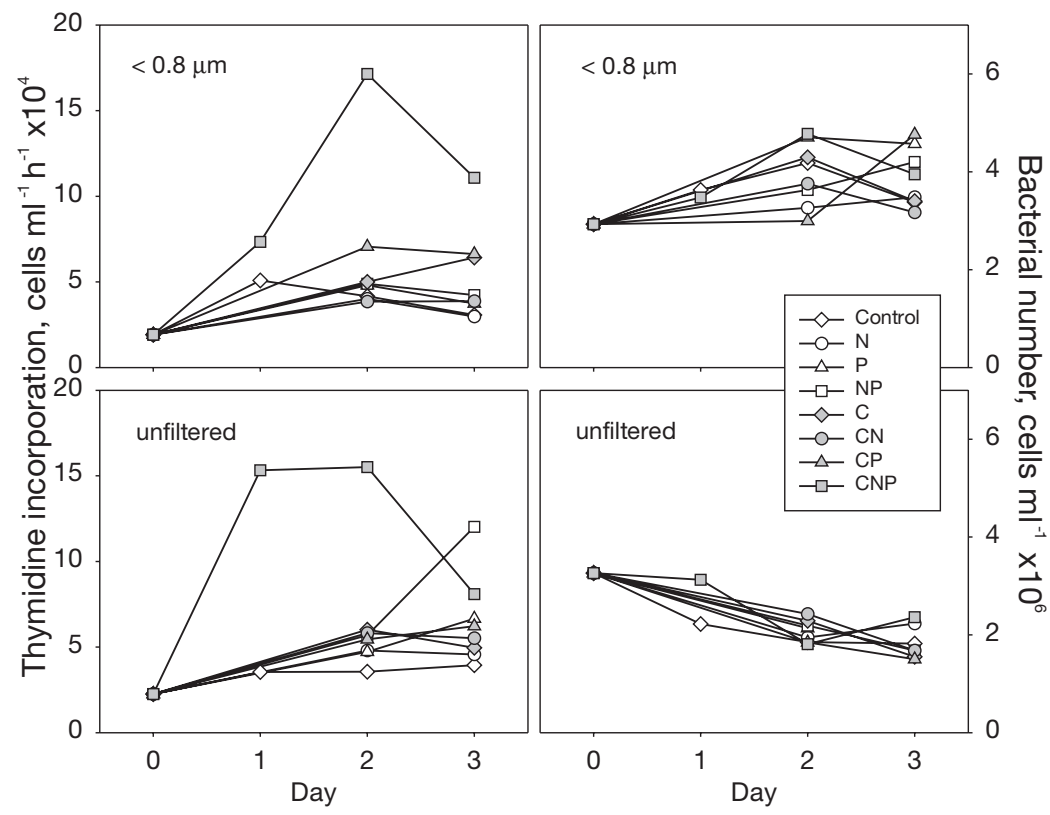

Fig. 2. Time course of bacterial production and abundance in the predator-free $(<0.8 \mu \mathrm{m})$ and unfiltered treatments in the 1997 experiment. Coefficient of variation $(\mathrm{CV} \%$ ) between the replicate treatments was 1 to $22 \%$ (mean $6 \%$ )

cyanobacteria and 8-fold concentration of dinoflagellates. Small filaments of Pseudanabaena acicularis were observed, but otherwise the algal communities were similar at the beginning of the $>90 \mathrm{~m}$ and $<40 \mu \mathrm{m}$ experiments. The abundances of heterotrophs were at the same level as in the $<40 \mu \mathrm{m}$ experiment, with the contribution to the microscopically observed biomass being 18\%. A total of $32 \%$ of the POC was in autotrophic organisms, leaving $50 \%$ of the POC in the detritus and mesozooplankton.

\section{Nutrient dynamics}

At the beginning of Expts $2(<40 \mu \mathrm{m}$ experiment) and $3(>90 \mu \mathrm{m})$, the concentrations of inorganic ammonium and phosphate were 0.25 to $0.35 \mu \mathrm{M} \mathrm{N}$ and 0.02 to $0.05 \mu \mathrm{M} P$ in the units without nutrient enrichment, and 6.1 $\mathrm{MM} \mathrm{N}$ and $0.7 \mu \mathrm{M} P$ in the units with the nutrient

Inorganic nutrients were almost depleted from the upper water column, and total phytoplankton biomass was low (Table 1). Unicellular picocyanobacteria constituted $50 \%$ of the total phytoplankton biomass. Of the picoplankton, less than $1 \%$ were the eukaryotic Micromonas pusilla. Photosynthetic nanoflagellates consisted mainly of Pedinellids, Cryptophytes, Pyramimonads and Chrysophytes. Although surface blooms of filamentous cyanobacteria had not yet developed, their share of the initial phytoplankton biomass was ca. $20 \%$ (mainly Nodularia spumigena and Aphanizomenon sp.). The abundance of heterotrophs was typically high for late summer; their share was $60 \%$ of the community biomass. Organisms constituted $57 \%$ of the total particulate organic carbon (POC), while the rest was detritus.

The >90 $\mu \mathrm{m}$ experiment was started $1 \mathrm{wk}$ after the $<40 \mu \mathrm{m}$ experiment, with a water sample from Stn T1 (Fig. 1). Because of the addition of the $>90 \mu \mathrm{m}$ concentrate, the total phytoplankton biomass was ca. 9fold larger than in the $<40 \mu \mathrm{m}$ experiment, which was mainly due to the 13-fold concentration of filamentous
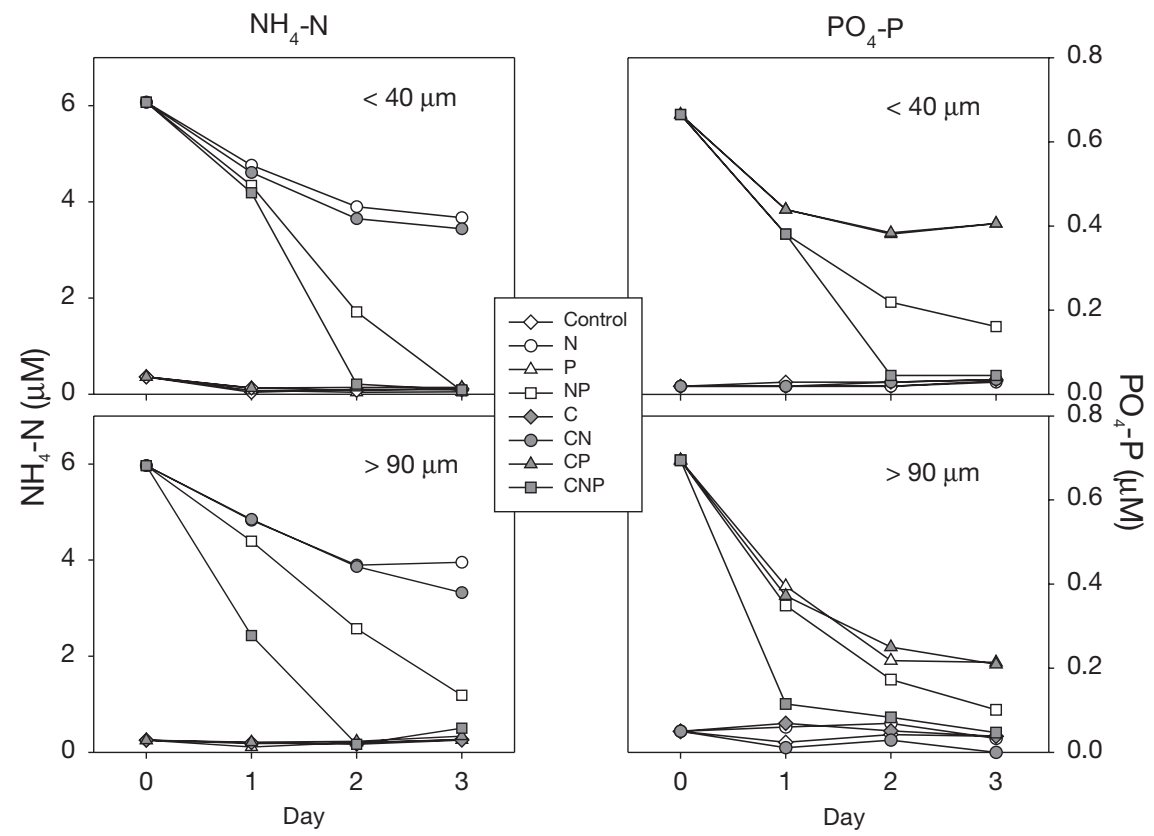

Fig. 3. Time course of inorganic nutrients $\left(\mathrm{NH}_{4}-\mathrm{N}\right.$, right panel and $\mathrm{PO}_{4}-\mathrm{P}$, left panel) in the 1998 experiments enrichment. In both experiments, added nutrients were most rapidly used, within $2 \mathrm{~d}$, in the CNP treatments (Fig. 3). In the NP treatment, nutrient depletion was never complete (1 and $20 \%$ of $\mathrm{NH}_{4}-\mathrm{N}$ and 24 and $15 \%$ of $\mathrm{PO}_{4}-\mathrm{P}$ was left at the end of the $<40$ and $>90 \mu \mathrm{m}$ experiments, respectively). In the single 
nutrient treatments, the percentage of ammonium and phosphate that was left at the end of the experiments was even higher (on average $60 \%$ for $\mathrm{NH}_{4}-\mathrm{N}$ and $46 \%$ for $\mathrm{PO}_{4}-\mathrm{P}$ ). Stimulation of the nutrient depletion by the other added nutrient could be calculated for the first experimental day ( 0 to $1 \mathrm{~d}$ ). The highest stimulation of both ammonium and phosphate depletion rates were observed by the addition of a bacterial carbon source combined with the other inorganic nutrient (either $\mathrm{N}$ or $\mathrm{P}$ ). The $\mathrm{C}$ addition alone did not speed up the depletion rate of either $\mathrm{N}$ or $\mathrm{P}$. This indicates a situation where phytoplankton was co-limited by both $\mathrm{N}$ and $\mathrm{P}$, and bacteria were limited by $\mathrm{C}, \mathrm{N}$ and $\mathrm{P}$.

\section{Primary production}

In the $<40 \mu \mathrm{m}$ experiment, PP decreased or showed no response during the experiment in all treatments except NP and CNP (Fig. 4). The total PP increase due to combined NP addition was almost entirely due to the 2 to $10 \mu \mathrm{m}$ algae, with the picoalgal contribution to the increase significantly smaller (ca. 1/3). However, picoalgae also benefited from the NP addition, by increasing their production 5-fold compared to the control. The increase in the PP was less apparent in the CNP treatment where the bacteria satisfied their carbon demand from the added labile carbon, and competed for inorganic nutrients. PP decreased in the $<2$ and $<10 \mu \mathrm{m}$ size classes, and started to level off in the 'total' $<40 \mu \mathrm{m}$ fraction during the third experimental day, when both ammonium and phosphate were exhausted in the experimental bottles (Fig. 4). In the $>90 \mu \mathrm{m}$ experiment, the PP rate decreased from the initial $17.5 \mu \mathrm{g} \mathrm{C}^{-1} \mathrm{~h}^{-1}$ in all treatments except NP and CNP, in which the rate increased to 30.2 and $20.9 \mu \mathrm{gC} \mathrm{l}^{-1} \mathrm{~h}^{-1}$, respectively (Fig. 4). The increase in PP was much less than in the $<40 \mu \mathrm{m}$ experiment, where most of the increase was due to $<10 \mu \mathrm{m}$ phytoplankton. The $>20 \mu \mathrm{m}$ size fraction (filamentous cyanobacteria) contributed, on average, $43 \%$ to the PP.

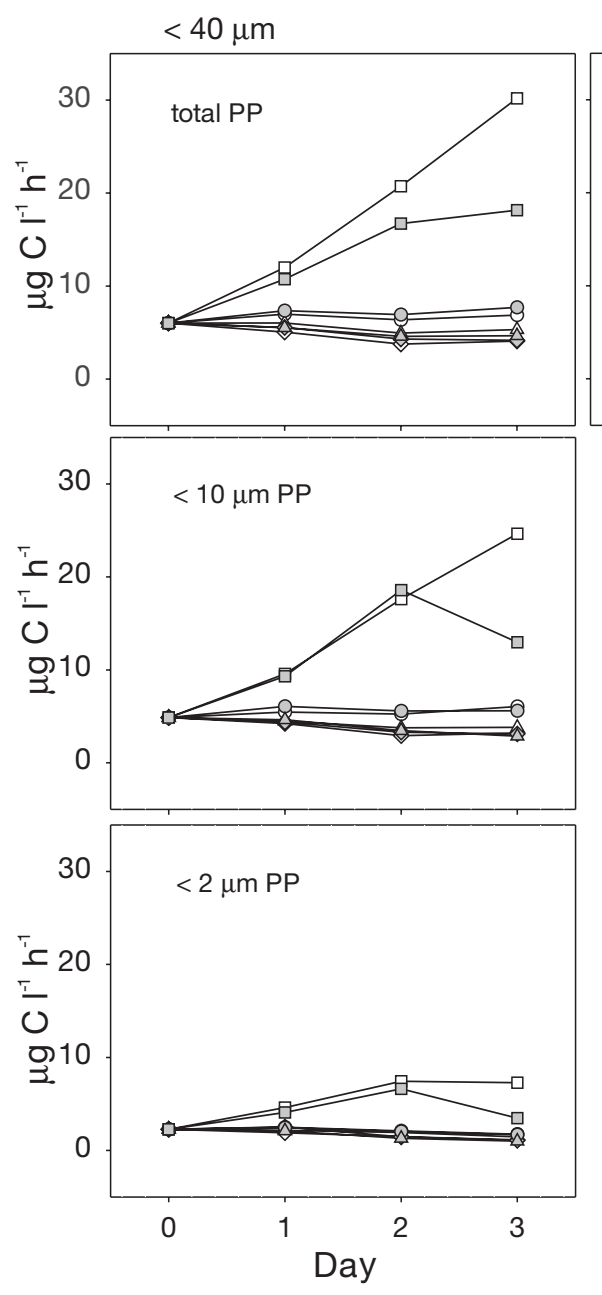

$>90 \mu \mathrm{m}$

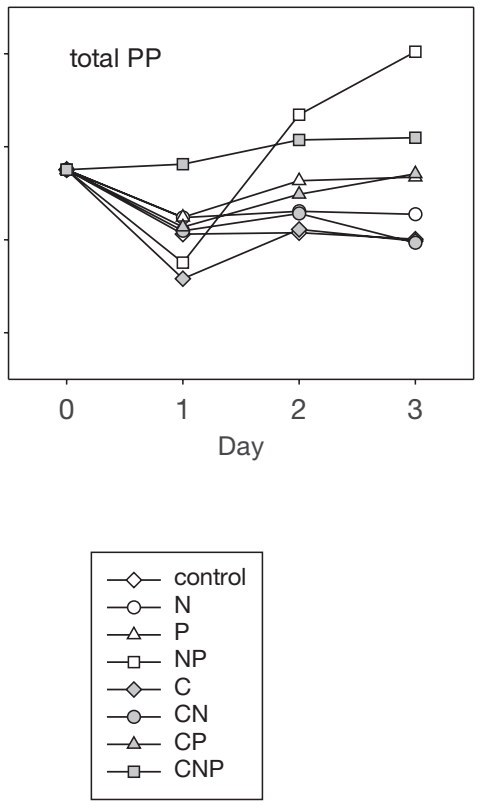

Fig. 4. Primary production (PP; particulate and dissolved) in the whole water sample (total PP) in the $<40$ and $>90 \mu \mathrm{m}$ experiments, and in $<10$ and $<2 \mu \mathrm{m}$ size fractions in the $<40 \mu \mathrm{m}$ experiment in 1998

\section{Bacterial production}

BP was stimulated by the CNP addition in the $<40 \mu \mathrm{m}$ experiment (Fig. 5). The thymidine incorporation rate increased 5fold (max. 5.2 $\mathrm{\mu g} \mathrm{C}^{-1} \mathrm{~h}^{-1}$ ) during the $3 \mathrm{ex}$ perimental days. The BP in the $<40 \mu \mathrm{m}$ experiment showed a pattern very similar to that in the predator-free treatment in 1997. The combined NP addition without sucrose, but also the single and combined nitrogen and carbon additions, slightly enhanced the thymidine incorporation at the beginning (Fig. 5). Apparently, shortage of carbon or nutrients started to limit the bacterial growth after the first experimental day, and the only significant response was observed with the combined addition of nitrogen, phosphorus and carbon. In the $>90 \mu \mathrm{m}$ experiment, BP responded to the nutrient and carbon (CNP) enrichment immediately during the first experimental day. The final level of BP, however, was lower than in the $<40 \mu \mathrm{m}$ experiment. The other treatments gave practically no response to the nutrient manipulations, except in the CP treatment at the end of the experiment. Integrated thymidine incorporation rates in the CNP treatment of the $<40 \mu$ m experiment was $25 \%$ higher than that of the >90 $\mu \mathrm{m}$ experiment. 
Fig. 5. Time course of bacterial production in the $<40$ and $>90 \mu \mathrm{m}$ experiments in 1998
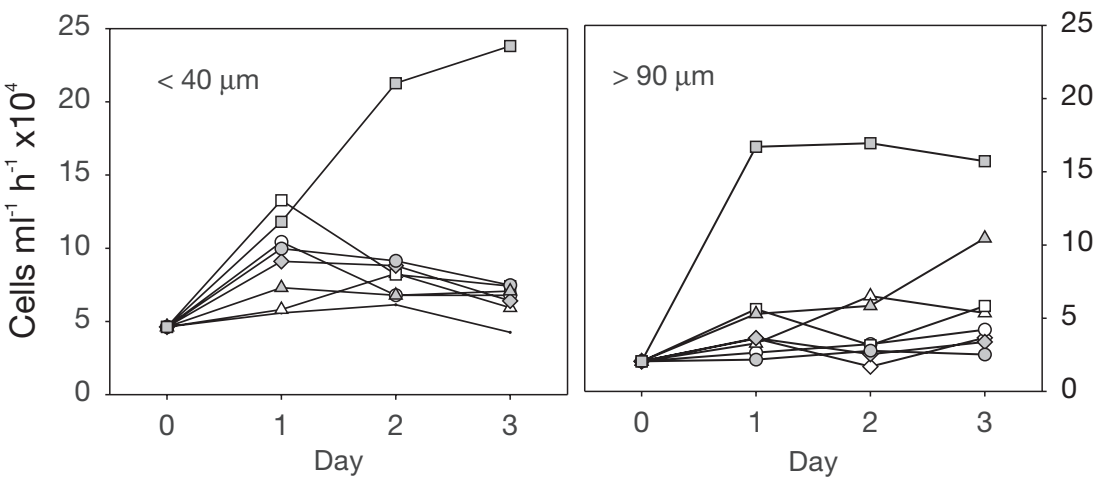

25

20

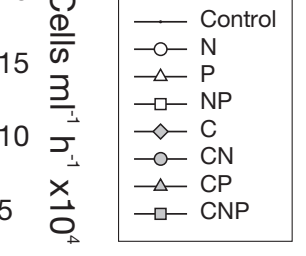

\section{Biomass development}

Chl a concentration followed roughly the same pattern as PP. The highest (4-fold) increase in the $<40 \mu \mathrm{m}$ experiment was observed in the NP treatment (Fig. 6), and a ca. 2.5-fold increase was observed in the CNP treatment. In the treatments with the single $\mathrm{N}$ or combined NC addition, chl a increased slightly, but otherwise remained at the initial level. The highest biomass increase in the $<40 \mu \mathrm{m}$ experiment was observed in the small nanoflagellate (2 to $10 \mu \mathrm{m})$ size fraction, whereas chl $a$ in the picoalgal fraction decreased slightly from the initial level (Fig. 6). In the $>90 \mu \mathrm{m}$ experiment, grazing by the concentrated zooplankton apparently reduced any increase in $\mathrm{chl}$ a concentration, because the maximum chl $a$ increase in the NP treatment was only ca. $60 \%$ compared to the control. In the $>90 \mu \mathrm{m}$ experiment, in which mesozooplankton was concentrated in the experimental bottles, the chl a increase was mainly due to the increase in the $<2 \mu \mathrm{m}$ size-fraction (Fig. 6).

Picoalgal abundances were high, from $4.5 \times 10^{5}$ to $1 \times 10^{6} \mathrm{cells} \mathrm{m}^{-1}$, with the highest abundances in both experiments found in treatments enriched with both $\mathrm{N}$ and $\mathrm{P}$ (Fig. 7), although with large irregular variations. This was partly due to small picocyanobacterial colonies that were included in the counts. Practically all picoalgae were cyanobacteria of Synechococcus-type. The cell volume of picoplanktonic cyanobacteria increased in all treatments from the initial $0.51{\mu m^{3}}^{3}$ to $0.86-0.80 \mu^{3}$. The largest cells were found in the $\mathrm{CN}$ treatment of both experiments.
Bacterial abundances varied in all experimental treatments (Fig. 7), but with no apparent trend except for a slight increase in the $>90 \mu \mathrm{m}$ experiment (Fig. 7). Bacterial cell volume increased from the initial $0.033{\mu \mathrm{m}^{3}}^{3}$ to $0.044-0.053 \mu \mathrm{m}^{3}$, with the largest increase in the $\mathrm{N}$ treatment.

Abundances of photosynthetic nanoflagellates increased from the initial 2.4 and $1.2 \times 10^{3} \mathrm{cells} \mathrm{ml}^{-1}$ $(<40$ and $>90 \mu \mathrm{m}$ experiments, respectively; Fig. 7). Cryptomonads were clearly favoured by the addition of nitrogen, especially when combined with phospho-

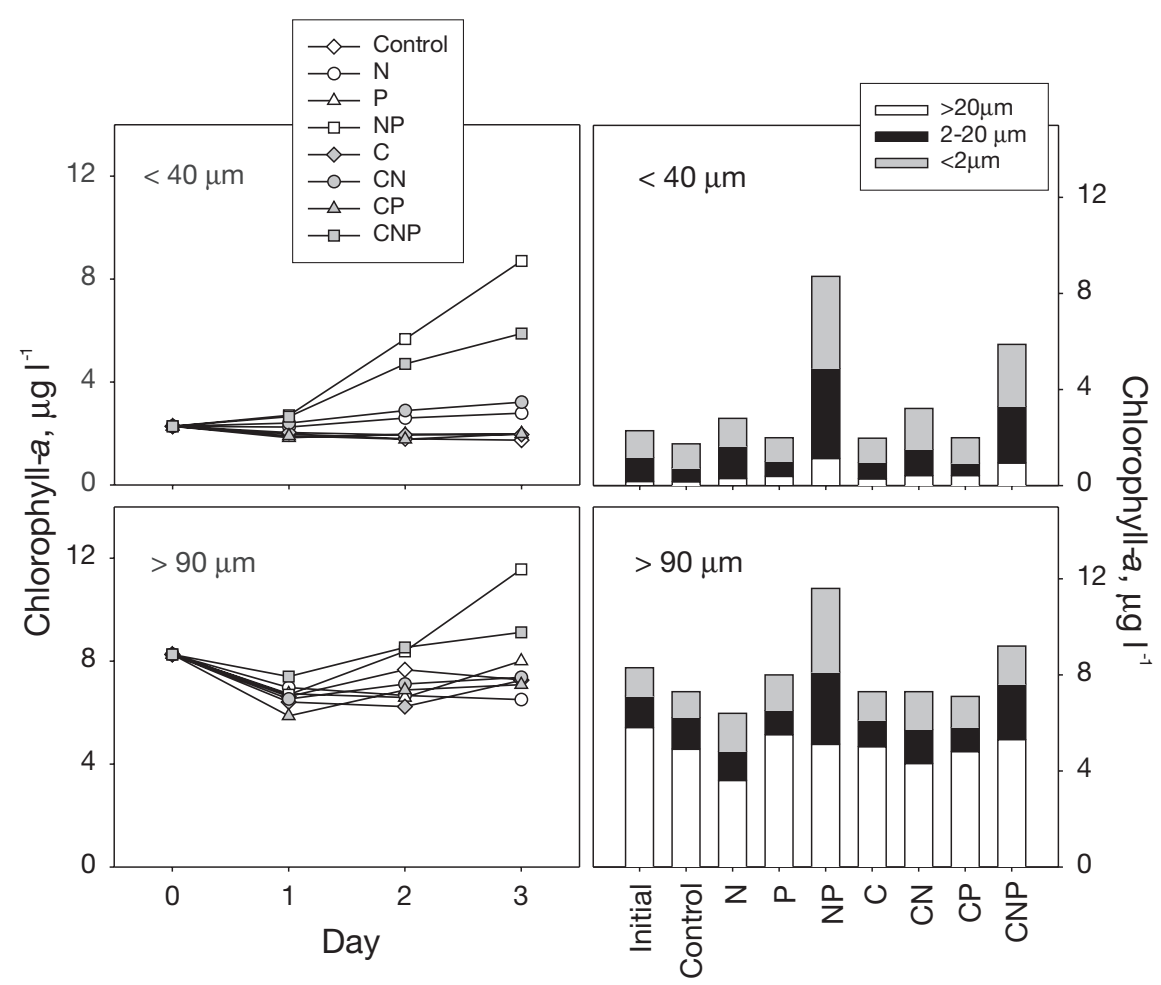

Fig. 6. Left panel: time course of chl a concentration in the $<40$ and $>90 \mu \mathrm{m}$ experiments. Right panel: chl $a$ in different size fractions at the beginning (initial) and end of the experiments 


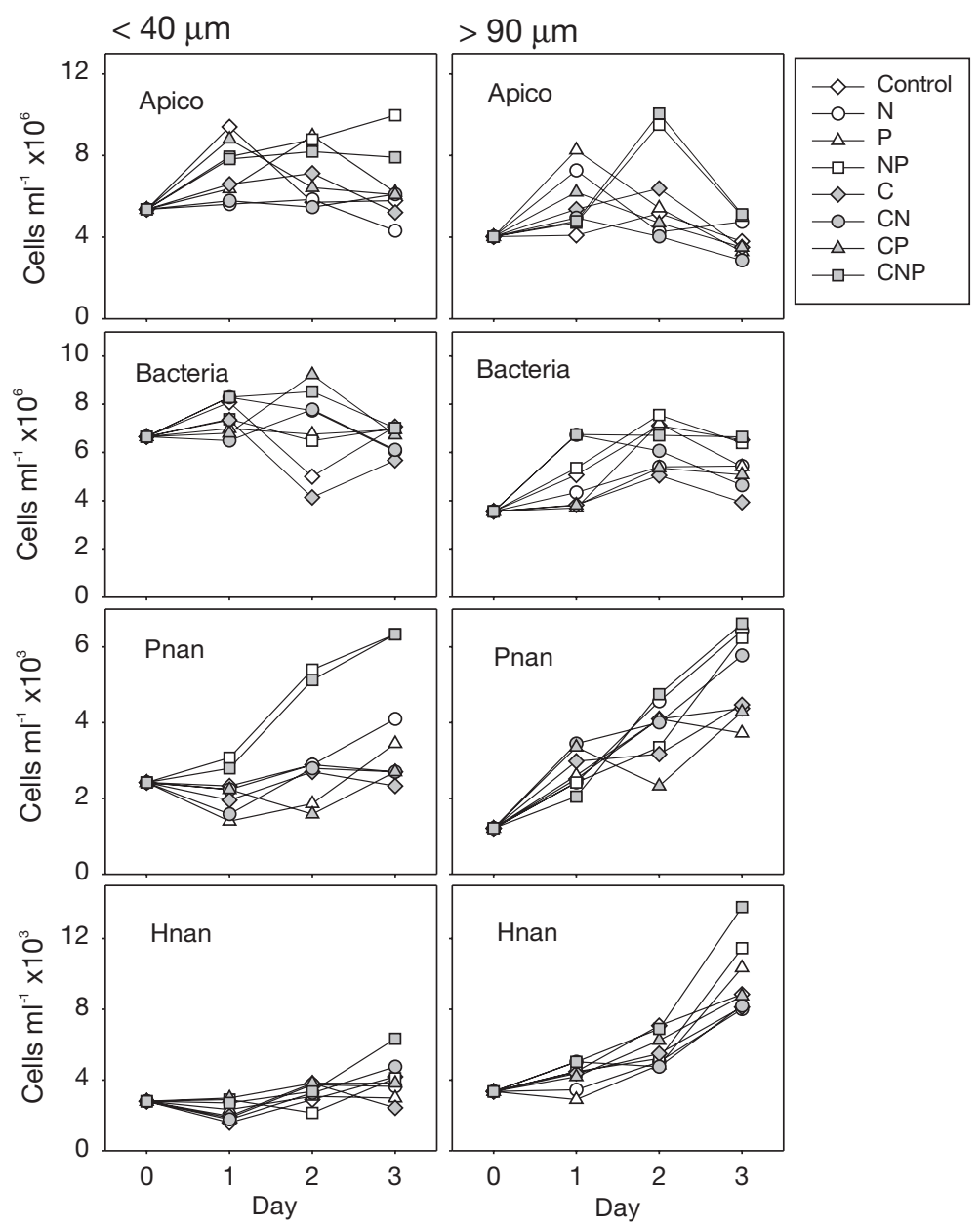

Fig. 7. Abundances of picoalgae, bacteria, photosynthetic nanoflagellates (Pnan), and heterotrophic nanoflagellates (Hnan) in the experiments. Left panel: $<40 \mu \mathrm{m}$ experiment, right panel: $>90 \mu \mathrm{m}$ experiment

rus in both experiments, while the pedinellids reached highest cell numbers in the CNP treatments. Other treatments did not show such significant responses.

Heterotrophic nanoflagellate abundances increased 3-fold from the initial value towards the end of the $>90 \mu \mathrm{m}$ experiment (Fig. 7), but only on average 1.4 -fold in the $<40 \mu \mathrm{m}$ experiment. This indicates that grazing control of the trophic cascade from mesozooplankton (in the $>90 \mu \mathrm{m}$ experiment) via ciliates prevailed in the community. In the CNP and NP additions, where picoplankton production was higher than in the other experimental treatments, the increase of heterotrophic nanoflagellates was most pronounced, indicating that they were at the same time limited by food availability.

Ciliate numbers decreased from the initial 5.1 and $5.6 \times 10^{4}$ cells $1^{-1}$ in both experiments
(Fig. 8), but less so in the $<40 \mu \mathrm{m}$ experiment. The difference between the $<40$ and $>90 \mu \mathrm{m}$ experiments implies that larger zooplankton controlled the ciliate abundance, while at the same time ciliate growth was limited by food availability, as seen by the higher abundances in the NP and CNP treatments, where the production of their prey-nanoflagellates and picoplankton — was elevated.

\section{Carbon budget $<40 \mu \mathrm{m}$ \\ Initial community}

In the initial plankton community, the share of heterotrophs was $59 \%$ of the total biomass (Fig. 9). BB (94 $\mathrm{g} \mathrm{C}^{-1}$ ) was ca. 2 times higher than that of the picoalgae $\left(57 \mu \mathrm{g} \mathrm{C}^{-1}\right)$, which, in turn, made up $60 \%$ of total phytoplankton biomass. Detritus comprised an approximately equal amount of carbon as picoplankton. The 'detritus' pool did not include mesozooplankton because it was excluded from the experimental units by the $40 \mu \mathrm{m}$ sieve. The ratio between the biomasses of heterotrophs and autotrophs (H:A) was 1.73 .

To compare the control, NP and CNP treatments during the experiment, $\mathrm{BP}$ and $\mathrm{PP}$ values were integrated over the $3 \mathrm{~d}$ period.

\section{Control treatment}

The picoplankton biomass, especially the autotrophic picocyanobacteria increased during the experiment (Fig. 9: control). Nano- and microphytoplankton biomass remained at the initial level, while filamentous cyanobacteria doubled their bio-

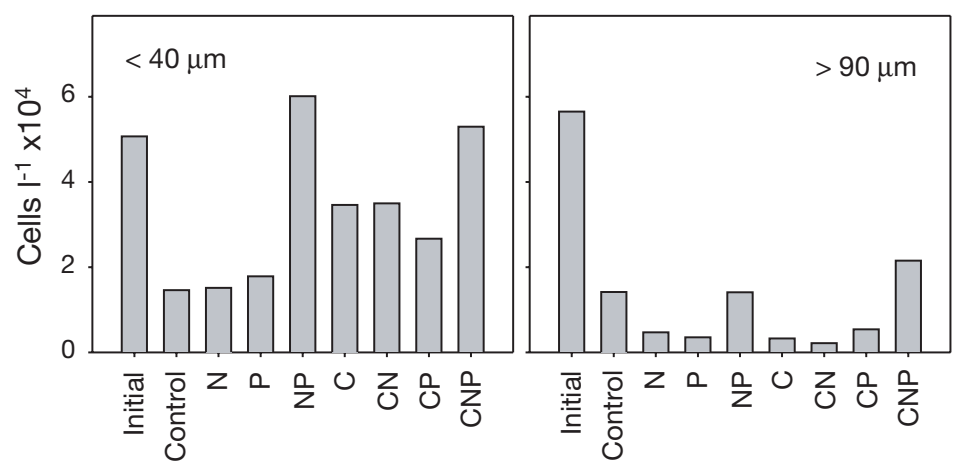

Fig. 8. Number of ciliates at the beginning (initial) and at the end of the experiments 
mass in all treatments. The contribution of heterotrophs decreased slightly to $43 \%$ of the biomass. Integrated PP during the experiment was $96 \mu \mathrm{g} \mathrm{C} 1^{-1}$, to which the $<2 \mu \mathrm{m}$ size fraction contributed $38 \%$ (36

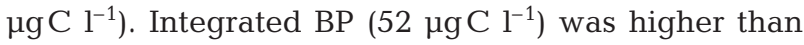
the picoalgal production and $54 \%$ of total PP. Practically all of the $<2 \mu \mathrm{m}$ PP was incorporated into the picoalgal biomass, while half of the total PP and $75 \%$ of BP were lost.

\section{NP treatment}

The addition of nitrogen and phosphorus led to a 4.5fold increase in PP of nano- and microphytoplankton fractions (200 $\mu \mathrm{g} \mathrm{C} 1^{-1}$ ) compared to the control, and more than an 8-fold increase in the picophytoplankton PP (105 $\mu \mathrm{g} \mathrm{C} 1^{-1}$; Fig. 9: NP), while BP doubled (91 $\mu \mathrm{g} \mathrm{C}$ $\left.1^{-1}\right)$. The contribution of the $<2 \mu \mathrm{m}$ size fraction to the total PP was slightly lower than in the control (34\%), whereas BP, compared to PP, was only $30 \%$. The major fraction $(67 \%)$ of the $<2 \mu \mathrm{m}$ PP was incorporated into the picocyanobacterial biomass, whereas 65 and $74 \%$ of nano- and microphytoplankton and $\mathrm{BP}$, respectively, were lost (Fig. 9: NP). Compared to the control treatment, the biomass increase in the NP treatment was 2-fold in the picoplankton fraction ('Synechococcus' and bacteria), and 9-fold in the nano- and microphytoplankton fraction, while the increase of the biomass of filamentous cyanobacteria was negligible (Fig. 6: NP). The heterotrophic nanoflagellate and ciliate biomass decreased slightly, and the detritus pool to ca. $67 \%$ from the initial.

\section{CNP treatment}

In the unit with the labile carbon source in addition to the inorganic ammonium and phosphate, BP (167 $\mu \mathrm{g}$ C $1^{-1}$ ) increased nearly 4 - and 2-fold compared to the control and NP unit, respectively, while the PP of both the pico- (89 $\left.\mu \mathrm{gC} 1^{-1}\right)$ and nano- and microphytoplankton $\left(159 \mu \mathrm{g} \mathrm{C}^{-1}\right)$ fractions were 20 to $25 \%$ lower than in the NP treatment (Fig. 9). The biomasses of pico- and nanoalgae increased as much as in the NP treatment. Microalgae and filamentous cyanobacteria increased their biomass $35 \%$ less than in the NP treatment. As a consequence of the labile carbon addition, $\mathrm{BB}$ increased $38 \%$ more than in the NP treatment. Most of the $>2 \mu \mathrm{m}$ PP and BP was lost (Fig. 9), but only $10 \%$ of the $<2 \mu \mathrm{m}$ PP. In contrast to the control and the NP treatments, heterotrophic nanoflagellate and microheterotroph (ciliate) biomasses increased slightly in the CNP treatment, indicating that the increased BP was directly channelled to the protists. The amount of detritus was higher in the CNP treatment than in the others (Fig. 6: CNP), and heterotroph biomass made up $41 \%$ of the total biomass.
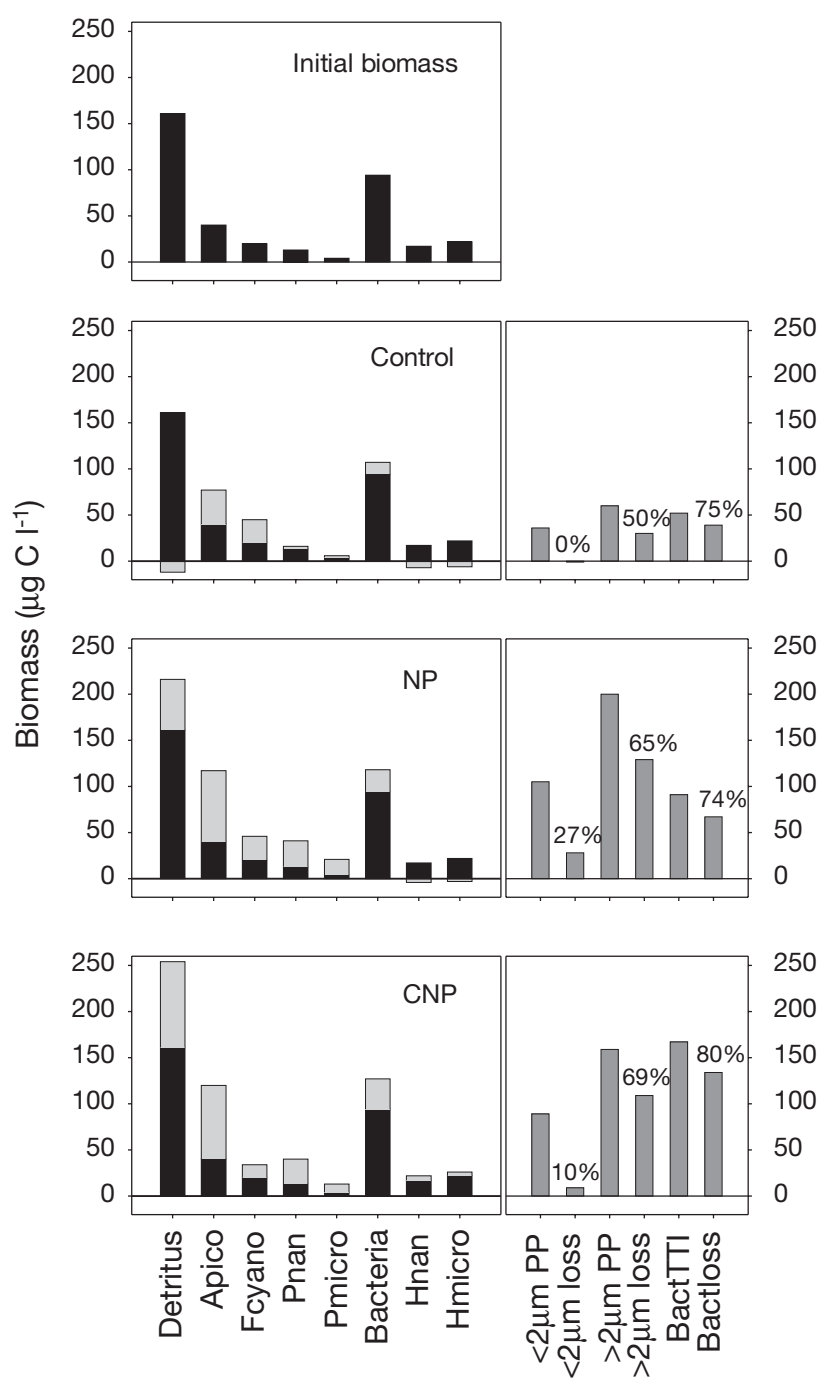

Fig. 9. Carbon budget of the $<40 \mu \mathrm{m}$ experiment. Left panel: biomasses of the organisms at the beginning (initial biomass) and at the end of the experiment in the control, NP and CNP units. Detritus: measured POC - microscopically derived biomass; Apico: picoplanktonic cyanobacteria and eukaryotes; Fcyano: filamentous and colonial cyanobacteria; Pnan: photosynthetic nanoflagellates; Pmicro: photosynthetic microplankton; bacteria: heterotrophic bacteria; Hnan: non-photosynthetic nanoflagellates; Hmicro: ciliates. Right panel: integrated production and loss rates of phytoplankton and bacteria. $<2 \mu \mathrm{m}$ PP: primary production in the $<2 \mu \mathrm{m}$ sizefraction $_{i}<2 \mu \mathrm{m}$ loss: primary production in the $<2 \mu \mathrm{m}$ sizefraction-biomass increase of picoautotrophs; $>2 \mu \mathrm{m}$ PP: primary production in the $>2 \mu \mathrm{m}$ size class; $>2 \mu \mathrm{m}$ loss: primary production in the $<2 \mu \mathrm{m}$ size fraction-biomass increase of Fcyano, Pnan and Pmicro; BactTTI: bacterial production; Bactloss: bacterial production-biomass increase of bacteria. Percentages show the share fraction of loss of the production: (loss/production) $\times 100$ 
Table 2. Carbon turnover rates (production:biomass, $\mathrm{P}: \mathrm{B}, \mathrm{d}^{-1}$ ) of bacteria and phytoplankton, and assimilation number (P:chl $a, \mathrm{~d}^{-1}$ ) of phytoplankton at the beginning (initial) and at the end of the $<40 \mu \mathrm{m}$ experiment with NP and CNP additions. See text for details. $<2 \mu \mathrm{m}$ phyto: picoplankton; $>2 \mu \mathrm{m}$ phyto: other phytoplankton

\begin{tabular}{|lccccc|}
\hline & & Initial & Control & NP & CNP \\
\hline P:B & Bacteria & 0.15 & 0.13 & 0.22 & 0.73 \\
& $<2 \mu$ m phyto & 0.27 & 0.02 & 0.13 & 0.06 \\
P:Chl $a$ & $>2 \mu$ phyto & 0.48 & 0.05 & 0.43 & 0.34 \\
& $<2 \mu$ phyto & 9.4 & 1.2 & 3.8 & 2.7 \\
& $>2 \mu$ m phyto & 15.2 & 4.3 & 9.5 & 9.0 \\
\hline
\end{tabular}

In spite of the elevated production rates, the same percentage $(25 \%)$ of BP appeared in the biomass of bacteria, whereas roughly 70 to $100 \%$ of the $<2 \mu \mathrm{m}$ PP was incorporated into the picoautotrophic biomass. For the $>2 \mu \mathrm{m}$ phytoplankton, the corresponding loss of PP was calculated to be ca. 50 to $69 \%$.

The H:A ratio decreased from the initial 1.73 to 0.92 in the control unit, 0.67 in the NP and 0.85 in the CNP treatment.

Carbon turnover rate (production:biomass, P:B) of bacteria increased from the initial $0.15 \mathrm{~d}^{-1}$ in the NP and CNP treatments, while both P:B and assimilation efficiency (production:chl a) of phytoplankton were lower at the end of the experiment compared to the initial community (Table 2).

\section{DISCUSSION}

\section{Phytoplankton nutrient limitation}

On the 1997 cruise dense cyanobacterial blooms in their late phase were floating in the mixed surface layer. The initial situation of the experiments in 1998 represented an earlier phase of the bloom: filamentous cyanobacterial biomass was fairly high, but because of the prevailing winds they were distributed in the water column and no surface accumulations were seen. Water temperature, ca. $15^{\circ} \mathrm{C}$, was still too low to allow intensive growth of Aphanizomenon flos-aquae and Nodularia spumigena (Kononen 1992), which were the dominating genera in the filamentous cyanobacterial community.

At the beginning of the $<40 \mu \mathrm{m}$ experiment in 1998, phytoplankton PP and biomass were low. PP in all size fractions was strongly co-limited by both nitrogen and phosphorus (cf. Fig. 4). Whereas the single N-addition increased the PP slightly, phosphorus was also needed to have a major effect on production. The same pattern was found in the response of chl a. Granéli et al. (1990) found overall N-limitation in the Baltic Proper, except during late-summer filamentous cyanobacterial blooms, when they found the system P-limited. Temporal variability in the nutrient limitation has been found to occur not only in coastal areas (e.g. Paasche \& Erga 1988, Kivi et al. 1993) but also in the open Baltic Sea (Seppälä et al. unpubl.).

The nutrient additions especially affected the nanoand picophytoplankton production, whereas the filamentous cyanobacteria were less affected. This was obvious also in the $>90 \mu \mathrm{m}$ experiment, in which PP was already initially at a higher level as a result of the addition of the $>90 \mu \mathrm{m}$ concentrate, and the responses were less pronounced. The increases in nano- and picoalgal abundance and biomass were apparent (cf. Fig. 7), as opposed to the less significant changes in filamentous cyanobacteria. In other experiments, carried out in this area (Seppälä et al. unpubl.) in the northern Baltic coastal zone (Kuuppo-Leinikki et al. 1994), it was found that nutrient enrichments in late summer are primarily channelled to nano- or microalgae, which, under a prolonged period of nutrient enrichment, may form monospecific blooms in mesocosms (e.g. Olli et al. 1996). It is often considered that picoplanktonic cyanobacteria do not experience nutrient limitation (Raven 1987, Wehr 1989) due to their large surface:volume ratio and they are capable of growing at the maximum growth rate in oligotrophic environments. However, in this experiment both their production and biomass showed clear responses to the combined additions of nitrogen and phosphorus, indicating that their growth was nutrient-limited. A decrease in the turnover rate and assimilation efficiency of $<2 \mu \mathrm{m}$ phytoplankton (cf. Table 2 ) indicated, however, that much of the increase in picoalgal production was connected to the increase in their biomass.

Lifting the water sample to the deck incubator obviously gave the filamentous cyanobacteria favourable conditions for growth. Their biomass also doubled from the initial level in the control treatment (cf. Fig. 9), and the addition of inorganic $\mathrm{N}$ and $\mathrm{P}$ did not further enhance their growth in the experiments. For this the filamentous cyanobacteria most probably used intracellular P reserves and N fixation (Kromkamp 1987, Larsson et al. 2001). Deficiency of iron has been found to limit the growth and photosynthesis of oceanic nitrogen-fixing cyanobacteria (e.g. Behrenfeld et al. 1996), and may perhaps occur also in the Baltic Sea (Stal et al. 1999).

\section{Limitation of BP}

BP was limited by both inorganic nutrients and a labile carbon source on both cruises, as indicated by the increased thymidine incorporation rate only in the 
CNP treatment. Bacterial cell volume increased the most in the $\mathrm{N}$ treatment. Many recent studies, carried out with bacterivore-free seawater or freshwater cultures, suggest that phosphate limits BP and biomass either alone, or in combination with labile DOC (Kuparinen \& Heinänen 1993, Thingstad et al. 1998, Carlsson \& Caron 2001). Rivkin \& Anderson (1997) reported from their study in the oligotrophic Sargasso Sea that labile carbon alone, or with either inorganic nitrogen or phosphorus, limited bacterial growth.

While most of the bacterial limitation bioassays have been carried out with predator-free seawater cultures, we included the whole microbial food web in our experiments, and in the $>90 \mu \mathrm{m}$ experiment we even concentrated phytoplankton and mesozooplankton communities. Even if nutrients were regenerated by protists and zooplankton during our study in 1998 (Caron \& Goldman 1990), and especially in the $>90 \mu \mathrm{m}$ experiment, the CNP limitation of bacteria was similar to that in 1997 with predator-free seawater cultures. This implies that regeneration processes could not provide inorganic nutrients or labile carbon rapidly enough to ensure the maximal growth of bacteria. The 5- and 3-fold turnover rates in the CNP treatment compared to the initial and control and the NP treatment, respectively (cf. Table 2) also indicate that bacteria were depleted by nitrogen, phosphorus, and carbon.

In the $>90 \mu \mathrm{m}$ experiment, bacterial thymidine incorporation increased little compared to the $<40 \mu \mathrm{m}$ experiment ( $>2$-fold difference). This may have been a methodological artefact, since we did not measure the conversion factor for TTI, but used the same conversion factor $\left(1 \times 10^{18}\right.$ cells per mole of incorporated thymidine; Heinänen \& Kuparinen 1992) in both experiments. On the other hand, the number of heterotrophic nanoflagellates increased considerably in the $>90 \mu \mathrm{m}$ experiment. Their selective grazing on large, elongated and dividing bacteria (Gonzales et al. 1990, Kuuppo-Leinikki 1990, Šimek \& Chrzanowski 1992) may have suppressed the BP in the >90 $\mu \mathrm{m}$ experiment.

\section{Competition between phytoplankton and bacteria}

When bacteria were provided with a labile carbon substrate, the depletion rate of ammonium and phosphate increased. PP and the increase of phytoplankton biomass ( $\mathrm{chl} \mathrm{a}$ ) were suppressed by 20 to $25 \%$ in the CNP treatment, when compared to the NP treatment in both experiments, even though the same amount of ammonium and phosphate was added. The inorganic nutrients were exhausted earlier from the CNP rather than the NP treatment (cf. Fig. 3). This could be due to the increased depletion rates of both $\mathrm{NH}_{4}-\mathrm{N}$ and $\mathrm{PO}_{4}$ -
$\mathrm{P}$ in the CNP treatment compared to the NP treatment through increased BP. This deficiency led to decreased $\mathrm{PP}$ in all size fractions on the last day of both experiments (cf. Fig. 4).

It is not certain whether this can, as such, be interpreted as bacterial superiority over phytoplankton in the competition of inorganic nutrients (Currie \& Kalff 1984). It is clear, however, that bacteria were colimited by labile carbon and inorganic nutrients, and when provided with $\mathrm{C}$, they took up the inorganic $\mathrm{NH}_{4}$ and $\mathrm{PO}_{4}$ from the water, leaving less for the phytoplankton.

\section{Food-web effects of increased production}

Trophic cascade control in the food web could be observed in the experiments. Even if the removal of resource-limitation by nutrient and labile carbon additions increased the production of bacteria ( $>3$-fold in CNP treatment over the control), a comparable increase in their biomass could not be observed. The grazer control of bacteria was further verified by the 1997 experiment, in which BB increased in the $<0.8 \mu \mathrm{m}$ prefiltered units, while a decrease was observed in the unfiltered units.

Heterotrophic nanoflagellates and ciliates are known to be the main grazers of bacteria and picocyanobacteria in aquatic food webs (e.g. Fenchel 1982, Sherr \& Sherr 1987, Kuuppo-Leinikki 1990, Caron et al. 1991, Kuosa 1991, Šimek et al. 1997). Unlike bacteria, the growth of picoplanktonic cyanobacteria seemed not to be grazer-controlled in these experiments. It is possible that the $<2 \mu \mathrm{m}$ PP measurements were slightly underestimated. There is evidence that part of picocyanobacterial cells may be retained on the $2 \mu \mathrm{m}$ filter during the prefiltration, especially when they form colonies during the late-summer phase (Pick \& Agbeti 1991, Uronen \& Kuuppo unpubl.). The share of the $<2 \mu \mathrm{m}$ size fraction of the whole $(<40 \mu \mathrm{m})$ PP was 52 to $60 \%$ in the control, NP and CNP treatments, which is reasonably high compared to the values published (e.g. Agawin et al. 2000), indicating that our PP measurements are not far from realistic.

In our experiments, heterotrophic nanoflagellates also seemed to be grazer-controlled. This was obvious from the difference in their growth in experiments without mesozooplankton $(<40 \mu \mathrm{m}$ prescreened experiment), in which ciliates could feed on the flagellates, and with mesozooplankton (>90 $\mu \mathrm{m}$ experiment), in which mesozooplankton eliminated the ciliates (cf. Figs. $7 \& 8$ ). The differences were smaller, however, than between the nutrient treatments. Ciliates on the next trophic level showed grazer control as well, by decreasing more, in numbers, in the experiment with 
mesozooplankton $(>90 \mu \mathrm{m})$ than without mesozooplankton $(<40 \mu \mathrm{m})$. On the other hand, when the production rates of their prey increased in the NP and CNP treatments, ciliate abundances also increased significantly over that in the other treatments (cf. Fig. 8). This agrees with the results from mesocosm experiments in Baltic coastal areas, where Kuuppo-Leinikki et al. (1994) found that the food-web effects of increased production are visible on the ciliate and mesozooplankton levels of the food web, whereas heterotrophic nanoflagellates were mainly controlled by grazing from above.

The increased BP in the CNP treatment also resulted in a slight biomass increase in heterotrophic nanoflagellate and ciliate biomasses. On the other hand, the increased PP of pico- and nanophytoplankton did not result in comparable biomass changes of protists. This indicates that the heterotrophic carbon pathway, bacteria-flagellate-ciliate or bacteria-ciliate, was more effective than the photosynthetic pathway in the microbial food web.

Duarte et al. (2000) calculated from their mesocosm experiment that nutrient enrichment shifts the biomass ratio of the planktonic food web towards dominance by autotrophs. The same happened in our $<40 \mu \mathrm{m}$ experiment. The initial H:A ratio (1.73) decreased in all treatments, but most (0.67) in the NP treatment. This implies a lower protozoan consumer biomass in relation to that of autotrophs, and a more direct channelling of PP to the mesozooplankton or into the dissolved pool. In this study, the percentage of total PP and BP not appearing in the biomasses of the organisms, i.e. the losses, was rather high (cf. Fig. 9). Moreover, the increase of the detritus pools accounted for 0 , 25 and $37 \%$ of the losses in the control, NP and CNP treatments, respectively, thereby leaving the remaining 63 to $100 \%$ as losses into the dissolved pool or by respiration.

\section{CONCLUSION}

In our experiments in the late-summer cyanobacterial bloom, we could not detect nutrient limitation in the growth of filamentous cyanobacteria. Nano- and microphytoplankton and picoalgae were limited by both nitrogen and phosphorus, and BP was co-limited by both inorganic nutrients and the labile carbon source. The additions of $\mathrm{NH}_{4}-\mathrm{N}$ and $\mathrm{PO}_{4}-\mathrm{P}$ were channelled mainly to flagellated nanoplankton. The increased BP was not observed as increased biomass, indicating grazing control by protists, whereas a large fraction of the measured $<2 \mu \mathrm{m}$ PP was accumulated into the picoautotrophic biomass. The increase in production at the bottom of the microbial food web led only to weak effects in the biomasses, because of tight grazing control in the food web at all trophic levels. The increase in BP by carbon addition increased biomasses at the higher trophic levels more than an increase in PP, indicating a tighter link on the heterotrophic part of the microbial food web.

Acknowledgements. We wish to thank U. Larsson and his group, and the crew of RV 'Baltica' for the cruises to the Gotland Deep. E. Salminen, M. Sjöblom (Tvärminne Zoological Station) and P. Kokkonen are acknowledged for the technical assistance and phytoplankton counts. Three anonymous referees gave valuable comments on the manuscript. This study was supported by the European Union through project BASYS within the MAST-programme (MAS3-CT96-0058) and the Finnish Environment Institute. This study is a contribution of the research group PELAG.

\section{LITERATURE CITED}

Agawin NSR, Duarte CM, Agustí S (2000) Nutrient and temperature control of the contribution of picoplankton to phytoplankton biomass and production. Limnol Oceanogr 45:591-600

Behrenfeld MJ, Bale AJ, Zbigniew SK, Aiken J, Falkowski PG (1996) Confirmation of iron limitation of phytoplankton photosynthesis in the equatorial Pacific Ocean. Nature 383:508-511

Bianchi TS, Engelhaupt E, Westman P, Andrén T, Rolff C, Elmgren R (2000) Cyanobacterial blooms in the Baltic Sea: natural or human-induced? Limnol Oceanogr 45:716-726

Bjørnsen PK (1986) Automatic determination of bacterioplankton biomass by image analysis. Appl Environ Microbiol 51:1199-1204

Blackburn N, Hagström Å, Wikner J, Cuadros-Hansson R, Bjørnsen PK (1998) Rapid determination of bacterial abundance, biovolume, morphology, and growth by neutral network-based image analysis. Appl Environ Microbiol. 64:3246-3255

Børsheim KY, Bratbak G (1987) Cell volume to cell carbon conversion factors for a bacterivorous Monas sp. enriched from seawater. Mar Ecol Prog Ser 36:171-175

Carlsson P, Caron DA (2001) Seasonal variation of phosphorus limitation of bacterial growth in a small lake. Limnol Oceanogr 46:108-120

Caron DA, Goldman JC (1990) Protozoan nutrient regeneration. In: Capriulo GM (ed) Ecology of marine protozoa. Oxford University Press, Oxford, p 283-306

Caron DA, Lim EL, Miceli G, Waterbury JB, Valois FW (1991) Grazing and utilization of chroococcoid cyanobacteria and heterotrophic bacteria by protozoa in laboratory cultures and a coastal plankton community. Mar Ecol Prog Ser 76: 205-217

Currie DJ, Kalff J (1984) A comparison of the abilities of freshwater algae and bacteria to acquire and retain phosphorus. Limnol Oceanogr 29:298-310

Downing JA, Osenberg CW, Sarnelle O (1999) Meta-analysis of marine nutrient-enrichment experiments: variation in the magnitude of nutrient limitation. Ecology 80: $1157-1167$

Duarte CM, Agustí S, Gasol JM, Vaqué, D, VazquezDominiguez E (2000) Effect of nutrient supply on the biomass structure of planktonic communities: an experimental test on a Mediterranean coastal community. Mar Ecol 
Prog Ser 206:87-95

Edler L (ed) (1979) Recommendations on methods for marine biological studies in the Baltic Sea. Phytoplankton and chlorophyll. Balt Mar Biol Publ 5:1-38

Fenchel T (1982) Ecology of heterotrophic microflagellates. IV. Quantitative occurrence and importance as bacterial consumers. Mar Ecol Prog Ser 9:35-42

Fuhrman J, Azam F (1982) Thymidine incorporation as a measure of heterotrophic bacterioplankton production in marine surface waters: evaluation and field results. Mar Biol 66:109-120

Gonzales JM, Sherr EB, Sherr BF (1990) Size-selective grazing on natural assemblages of estuarine flagellates and ciliates. Appl Environ Microbiol 56:583-589

Graziano LM, Geider RJ, Li WKW (1996) Nitrogen limitation of North Atlantic phytoplankton: analysis of physiological condition in nutrient enrichment experiments. Aquat Microb Ecol 11:53-64

Granéli E (1984) Algal growth potential and limiting nutrients for phytoplankton production in Öresund eater of Baltic and Kattegat origin. Limnologica 15:563-569

Granéli E (1987) Nutrient limitation of phytoplankton biomass in a brackish water bay highly influenced by river discharge. Estuar Coast Shelf Sci 25:555-565

Granéli E, Schultz S, Schiewer U, Gedziorowska D, Kaiser W, Plinski M (1988) Is the same nutrient limiting potential phytoplankton biomass formation in different coastal areas of the Southern Baltic? Kieler Meeresforsch Sonderh 6:191-202

Granéli E, Wallström $\mathrm{K}$, Larsson U, Granéli W, Elmgren R (1990) Nutrient limitation of primary production on the Baltic Sea area. Ambio 19:142-151

Haas LW (1982) Improved epifluorescence microscopy for observing planktonic micro-organisms. Annu Inst Oceanogr Paris 58:261-266

Hameed HA, Kilinc S, McGowan S, Moss B (1999) Physiological tests and bioassays: aids of superfluities to the diagnosis of phytoplankton nutrient limitation? A comparative study in the Broads and the Meres of England. Eur J Phycol 34:253-269

Hecky RE, Kilham P (1988) Nutrient limitation of phytoplankton in freshwater and marine environments: a review of recent evidence on the effects of enrichment. Limnol Oceanogr 33:796-822

Heinänen A, Kuparinen J (1992) Response of bacterial thymidine and leucine incorporation to nutrient $\left(\mathrm{NH}_{4}, \mathrm{PO}_{4}\right)$ and carbon (sucrose) enrichment. Ergeb Limnol 37:241-251

Heinänen A, Kononen K, Kuosa H, Kuparinen J, Mäkelä K (1995) Bacterioplankton growth associated with physical fronts during a cyanobacterial bloom. Mar Ecol Prog Ser 116:233-245

HELCOM (1996) Third periodic assessment of the state of the marine environment of the Baltic Sea, 1989-1993. Baltic Sea Environment Proceedings 64B, Helsinki Commission, Baltic Sea Environment Protection Commission. Oy Edita Ab, Helsinki

Hobbie JER, Daley J, Jasper S (1977) Use of Nuclepore filters for counting bacteria by fluorescence microscopy. Appl Environ Microbiol 33:1225-1228

Holmboe N, Jensen HS, Andersen FØ (1999) Nutrient addition bioassays as indicators of nutrient limitation of phytoplankton in an eutrophic estuary. Mar Ecol Prog Ser 186: 95-104

Johannes RE (1965) Influence of marine protozoa on nutrient regeneration. Limnol Oceanogr 10:434-442

Kahru M, Horstmann U, Rud O (1994) Satellite detection of increased cyanobacteria blooms in the Baltic Sea: Natural fluctuation or ecosystem change? Ambio 23:469-472

Kivi K, Kaitala S, Kuosa H, Kuparinen J, Leskinen E, Lignell R, Marcussen B, Tamminen T (1993) Nutrient limitation and grazing control of the Baltic plankton community during annual succession. Limnol Oceanogr 38:893-905

Kononen K (1992) Dynamics of the toxic cyanobacterial blooms in the Baltic Sea. Finnish Mar Res 261:1-36

Kononen K, Kuparinen J, Mäkelä K, Laanemets J, Pavelson J (1996) Initiation of cyanobacterial blooms in a frontal region at the entrance to the Gulf of Finland, Baltic Sea. Limnol Oceanogr 41:98-112

Koroleff F, Grasshoff K (1983) Determination of nutrients. In: Grasshoff K (ed) Methods of seawater analysis. Verlag Chemie, Weinheim, p 125-188

Kromkamp J (1987) Formation and functional significance of storage products in cyanobacteria. NZ J Mar Freshw Res 21:457-465

Kuosa H (1988) Enumeration of autotrophic and heterotrophic flagellates in Baltic Sea samples - a comparison of microscopical methods. Arch Hydrobiol Beih Ergebn Limnol 31: 301-306

Kuosa H (1991) Picoplanktonic algae in the northern Baltic Sea: seasonal dynamics and flagellate grazing. Mar Ecol Prog Ser 73:269-276

Kuparinen J, Heinänen A (1993) Inorganic nutrient and carbon controlled bacterioplankton growth in the Baltic Sea. Estuar Coast Shelf Sci 37:271-285

Kuuppo-Leinikki P (1990) Protozoan grazing on planktonic bacteria and its impact on bacterial population. Mar Ecol Prog Ser 63:227-238

Kuuppo-Leinikki P, Autio R, Hällfors S, Kuosa H, Kuparinen J, Pajuniemi R (1994) Trophic interactions and carbon flow between picoplankton and protozoa in pelagic enclosures manipulated with nutrients and a top predator. Mar Ecol Prog Ser 107:89-102

Larsson U, Hajdu S, Walve J, Elmgren R (2001) Baltic Sea nitrogen fixation estimated from the summer increase in upper mixed layer total nitrogen. Limnol Oceanogr 46: $811-820$

Li WKW (1986) Experimental approaches to field measurements: methods and interpretation. In: Platt $\mathrm{T}, \mathrm{Li}$ WKW (eds) Photosynthetic picoplankton, 214. Canadian Bulletin of Fisheries and Aquatic Science, Ottawa, p 251-286

Lignell R (1992) Problems in filtration fractionation of ${ }^{14} \mathrm{C}$ primary productivity samples. Limnol Oceanogr 37:172-178

Mallin MA, Cahoon LB, McIver MR, Parsons DC, Shank GC (1999) Alternation of factors limiting phytoplankton production on the Cape Fear river estuary. Estuaries 22: $825-836$

Olli K, Heiskanen AS, Seppälä J (1996) Development and fate of Eutreptiella gymnastica bloom in nutrient enriched enclosures in the coastal Baltic Sea. J Plankton Res 18: $1587-1604$

Paasche E, Erga S (1988) Phosphorus and nitrogen limitation of phytoplankton in the inner Oslofjord (Norway). Sarsia 73:229-243

Pick FR, Agbeti M (1991) The seasonal dynamics and composition of photosynthetic picoplankton communities in temperate lakes in Ontario, Canada. Int Rev Ges Hydrobiol 76:565-580

Raven JA (1987) Physiological consequences of extremely small size for autotrophic organisms in the sea. In: Platt T, Li WKW (eds) Photosynthetic picoplankton. Can J Fish Aquat Sci 214:1-17

Raven JA (1998) The twelfth Tansey Lecture. Small is beautiful: the picophytoplankton. Funct Ecol 12:503-513

Rivkin RB, Anderson MR (1997) Inorganic nutrient limitation 
of oceanic bacterioplankton. Limnol Oceanogr 42: $730-740$

Sakshaug E, Olsen Y (1986) Nutrient status of phytoplankton blooms in Norwegian waters and algal strategies for nutrient competition. Can J Fish Aquat Sci 43:389-396

Seppälä J, Tamminen T, Kaitala S (1999) Experimental evaluation of nutrient limitation of phytoplankton communities in the Gulf of Riga. J Mar Syst 23:107-126

Sherr EB, Sherr BF (1987) High rates of consumption of bacteria by pelagic ciliates. Nature 335:348-351

Šimek K Chrzanowski TH (1992) Direct and indirect evidence of size-selective grazing on pelagic bacteria by freshwater nanoflagellates. Appl Environ Microbiol 58:3715-3720

Šimek K, Harman P, Nedoma J, Pernthaler J, Springmann D, Vrba J, Psenner R (1997) Community structure, picoplankton grazing and zooplankton control of heterotrophic nanoflagellates in a eutrophic reservoir during the summer phytoplankton maximum. Aquat Microb Ecol 12: 49-63

Sivonen K, Kononen K, Carmichael WW, Dahlem AM, Rinehart KL, Kiviranta J, Niemelä SI (1989) Occurrence of the hepatotoxic cyanobacterium Nodularia spumigena in the Baltic Sea and structure of the toxin. Appl Environ Microbiol 55:1990-1995

Smith DC, Azam F (1992) A simple, economical method for measuring bacterial protein synthesis rates in seawater using ${ }^{3} \mathrm{H}$-leucine. Mar Microb Food Webs 6:107-114

Editorial responsibility: Karin Lochte, Kiel, Germany
Stal L, Staal M, Villbrandt M (1999) Nutrient control of cyanobacterial blooms in the Baltic Sea. Mar Ecol Prog Ser 18:165-173

Steemann-Nielsen E (1952) The use of radioactive carbon $\left({ }^{14} \mathrm{C}\right)$ for measuring organic production in the sea. J Cons Perm Int Explor Mer 18:117-140

Taylor GT, Iturriaga R, Sullivan CV (1985) Interactions of bacterivorous grazers and heterotrophic bacteria with dissolved organic matter. Mar Ecol Prog Ser 23:129-141

Thingstad TF, Zweifel UL, Rassoulzadegan F (1998) P limitation of heterotrophic bacteria and phytoplankton in the northwest Mediterranean. Limnol Oceanogr 43:88-94

Tikkanen T (1986) Kasviplanktonopas. Suomen Luonnonsuojelun Tuki, Helsinki, p 278

Utermöhl H (1958) Zur Vervollkommnung der Quantitativen Phytoplankton-Methodik. Mitt Internat Ver Theor Angew Limnol 9:1-38

Wehr JD (1989) Experimental tests of nutrient limitation on freshwater picoplankton. Appl Environ Microbiol 55: 1605-1611

Zevenboom W (1986) Ecophysiology in nutrient uptake, photosynthesis and growth. In: Platt T, Li WKW (eds) Photosynthetic picoplankton, 214. Canadian Bulletin of Fisheries and Aquatic Science, Ottawa, p 391-422

Zweifel UL, Norrman B, Hagström Å (1993) Consumption of dissolved organic carbon by marine bacteria and demand for inorganic nutrients. Mar Ecol Prog Ser 101:23-32

Submitted: September 25, 2002; Accepted: January 13, 2003 Proofs received from author(s): March 27, 2003 